\title{
BIOLOGICAL NOTES ON TWO SPECIES OF \\ SERICOPHORUS FROM AUSTRALIA (HYMENOPTERA: SPHECIDAE)
}

\section{By Robert W. Matthews and Howard E. Evans ${ }^{1}$}

Sericophorus is a genus of robust, often iridescent bee-like wasps belonging to the larrine tribe Miscophini. The genus is endemic to Australia and Tasmania and possibly extends into New Guinea, where one male has been taken (A. S. Menke, pers. comm.). Riek (1970) reports 14 species from Australia. Males are unusual in that the antennae typically consist of only I2 segments instead of the 13 found in most male sphecid wasps.

The only previous biological observations on members of this genus are those by Rayment (1955a, b). His papers include miscellaneous notes on at least six species occurring in Victoria, Western Australia, and New South Wales, and present the main behavioral features of the genus. Unfortunately, the rambling conversational style adopted by Rayment makes it difficult to sort out the facts in his reports, and indeed, it is often unclear as to which species his discussions refer. Numerous fragmentary observations, suchw as the occurrence of two adults in the same nest of $S$. sydneyi Rayment (1955b, pp. 75-76) and S. victoriensis Rayment (1955a, p. I37, presumed subterranean mating in $S$. viridis roddi Rayment (1955b, p. 74), and apparent territoriality in $S$. sydneyi females (1955b, p. 75) were not confirmed in the present very incomplete studies. We did, however, confirm two unusual behavior patterns reported by Rayment: hunting in the early morning hours and capture of only male flies. Rayment found this to be true in $S$. teliferopodus Rayment, and we found it to be the case in $S$. viridis Saussure.

Our observations concern two forms not previously studied, $S$. viridis Saussure and $S$. relucens Smith. Included also is the first detailed larval description for the genus, and notes on a parasitic nyssonine wasp, Acanthostethus portlandensis (Rayment).

\section{Sericophorus viridis Saussure}

With one exception, all of our notes on $S$. viridis were made on

\footnotetext{
${ }^{1}$ Respectively, Department of Entomology, University of Georgia, Athens, Georgia 30601, and Museum of Comparative Zoology, Harvard University, Cambridge, Massachusetts 02138. Research supported by the National Science Foundation, U. S. A., Grant No. GB 8746.

Manuscript received by the editor March 10, 1971.
} 


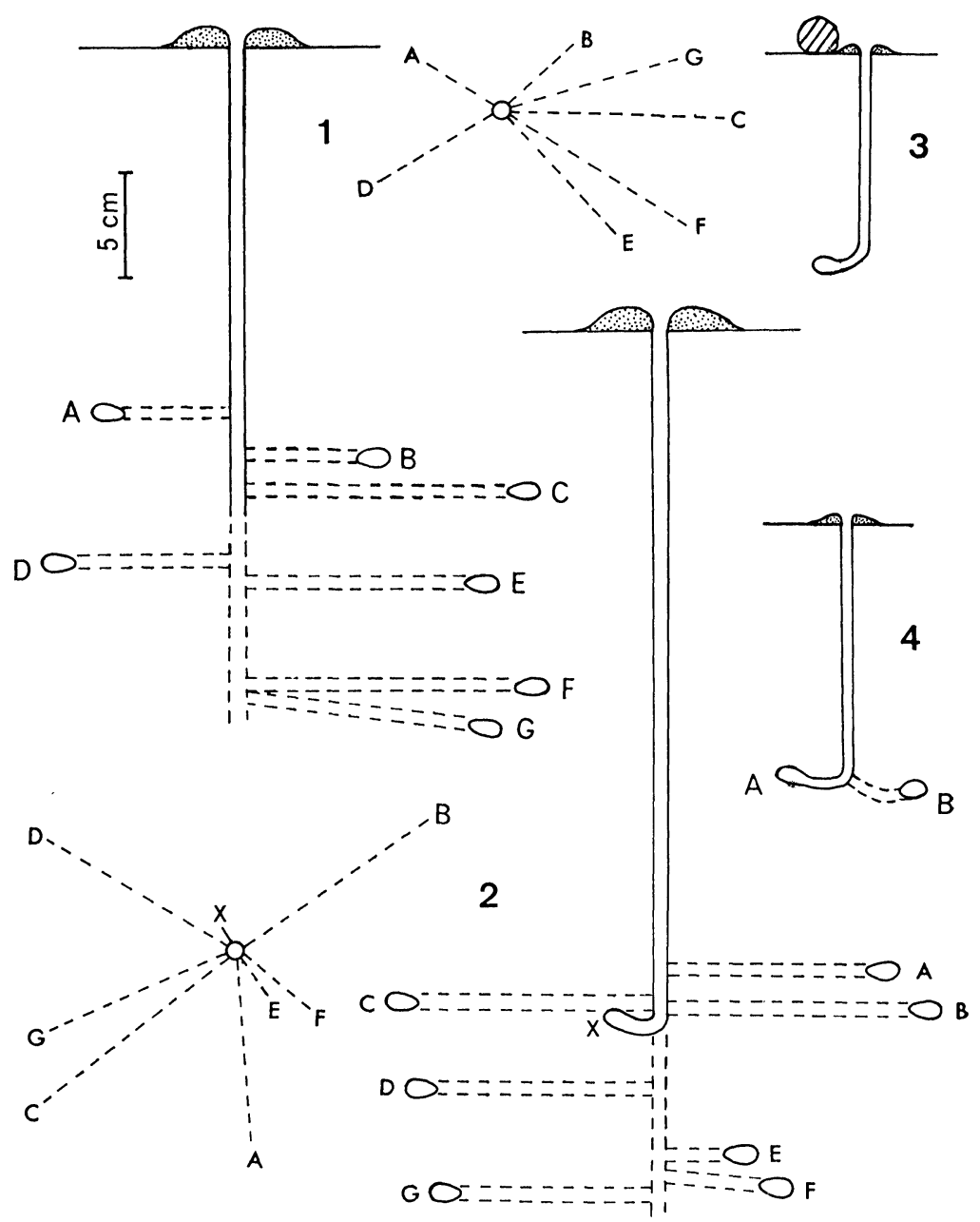

Fig. 1. S. viridis, no. A 258, shown in profile (left) and plan (right). Cells $B$ and $E$ contained eggs, cell $F$ a cocoon. Contents of the other cells were molded. Fig. 2. S. viridis, no. AM 144, shown in plan (left) and profile (right). Eggs or fresh flies were present in cells $\mathrm{A}, \mathrm{B}, \mathrm{C}$ and D. The contents of cell $\mathrm{E}$ were molded; cell $\mathrm{F}$ contained a half-grown larva and cell $G$ a cocoon. The blind end of the burrow is indicated by an $X$. Fig. 3. S. relucens, no. AM 133 , in profile. Fig. 4. S. relucens, no. AM 152 , in profile; both cells contained fresh flies. 
a large colony nesting on the lower slopes of Black Mountain, Canberra, A. C. T., behind the C. S. I. R. O. Entomology buldings. The soil containing nests was a sandy loam of rather firm and uniform consistency forming a layer from 15 to $40 \mathrm{~cm}$ deep overlying coarse gravel and small rocks. Possibly these areas were parts of former stream channels on the mountain, since a few meters away the soil graded rather abruptly into loamy to hard clay, which characterized most of the lower slopes of Black Mountain.

This wasp was extremely successful in this area and active nests were found from mid-December through April. Nests were concentrated in three more or less contiguous areas. On 13 February 1970 , the largest of these nesting aggregations contained 88 active nests, concentrated in an area of about $8 \times 2$ meters along the fence bordering the Botanical Gardens. This area had been harrowed for a fire break earlier in the summer and lacked vegetational cover. The smaller aggregations were estimated to contain 40-50 active nests, and were in adjacent areas having a sparse herbaceous cover. Inter-nest distances were variable, but on several occasions active nests were noted within $5 \mathrm{~cm}$ of one another.

Nesting Behavior. - Nineteen nests were excavated by the authors between 6 January and I8 April, I970 (note numbers A I93, A 22 I, A 251, A 252, A 259-261, A 306, AM I4I-I44, AM 153, AM 2I7). Representative nests are illustrated in Figures $I$ and 2. Females dig a more or less vertical main shaft from $10-50 \mathrm{~cm}$ deep (ave. $2 \mathrm{I} .3 \mathrm{~cm}$ ), and construct up to 23 cells (ave. 5.6) at depths of $10-50 \mathrm{~cm}$. Cells are placed in a radiating pattern, each at the end of a more or less horizontal lateral burrow extending $\mathrm{I}-\mathrm{I} 4 \mathrm{~cm}$ (ave. $7.0 \mathrm{~cm}$ ) from the main tunnel. Cells are elliptical and more or less horizontal, measuring about $9 \times 18 \mathrm{~mm}$. The lateral tunnels leading to the cells are approximately perpendicular to the main shaft or inclined slightly upwards. A single cell is excavated at the end of each lateral tunnel, and after provisioning and oviposition, the tunnel is completely refilled. In some nests (e.g., note AM I44) the first made or oldest cells were apparently deepest and more recent cells closest to the surface. However, in one 7-celled nest the freshest flies and eggs were in the deepest cells (A. 260), and in some nests the newer cells appeared to be interspersed at various depths between older cells (e.g., A 26r).

Nests are made conspicuous by the accumulation of a prominent rim-like mound, 6-8 $\mathrm{cm}$ across and $0.5-2.0 \mathrm{~cm}$ deep, surrounding the 7-8 $\mathrm{mm}$ diameter entrances (Fig. 9). These buff-colored mounds contrasted strikingly with the gravish soil surface, and were easily 


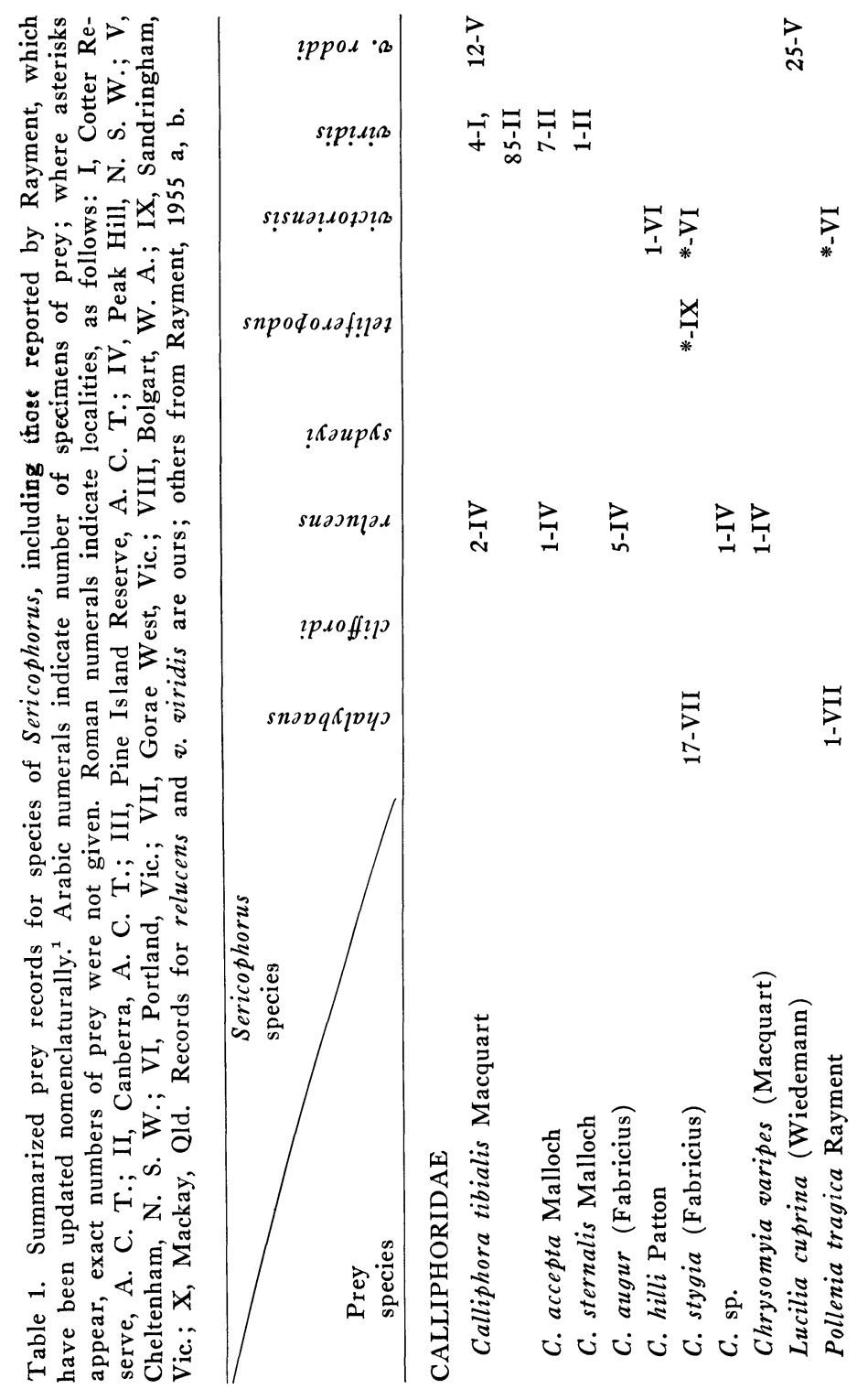




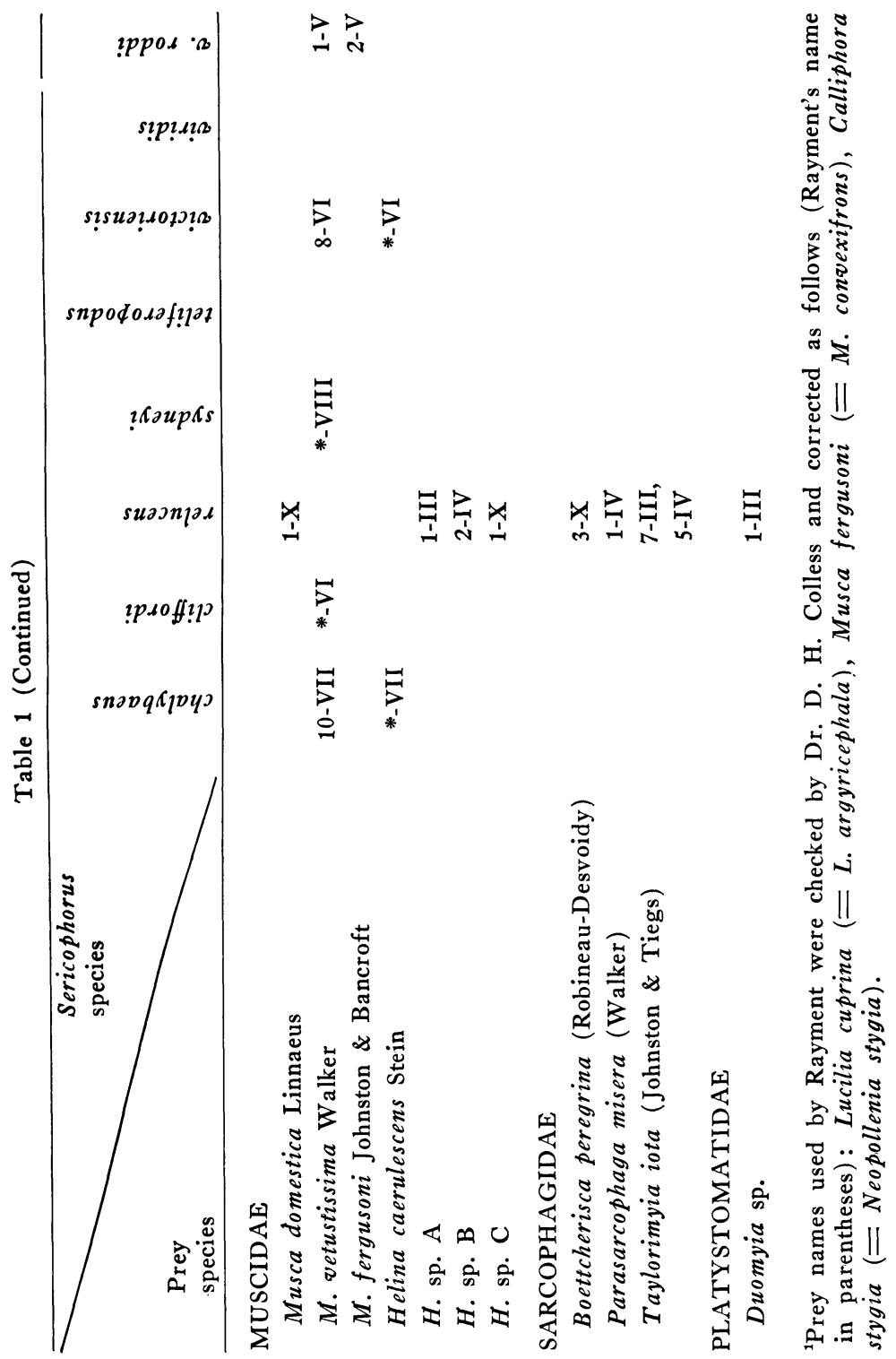


located. Brief observations of digging behavior indicated that the soil is pushed out a load at a time, the females emerging abdomen first, with a pellet of soil held ventrally between the curved tip of the abdomen and the hind legs. At the nest entrance the soil is thrust out, apparently by the hind legs, and simply accumulates as a rim about the entrance, with no leveling being done. Apparently most digging is done at night or in the very early morning, for when we checked the colony early on days following heavy rains, numerous freshly made mounds were always present.

The Black Mountain colony exhibited a very decided preference for a single blowfly species, Calliphora tibialis Macquart (Table I). The constancy over the entire nesting season to this one species was remarkable, and indeed, the only nest from a different locality (Note A I93, Cotter Reserve, AC.T.) also contained exclusively $C$. tibialis. The only exceptions at the Black Mountain colony were a single individual of $C$. sternalis Malloch found in a nest excavated on 7 January (early season) and 7 individuals of $C$. accepta Malloch, all taken on the same day (4 March) near the end of the nesting season, when $C$. tibialis populations may have been declining.

By visiting the colony at different times of the day we were able to establish that most, if not all, provisioning occurred during the first hour after the morning sun first hit the tops of the trees. On 26 February, a completely clear morning, much provisioning occurred between $6: 20$ and 6:50 a.m. On 28 February the sun was behind clouds until $6: 55$; no provisioning was noted between $6: 00$ and $6: 55$, but after that time, until $7: 45$, many flies were brought in. The temperature at $6: 00$ was $58^{\circ} \mathrm{F}$; during the period of provisioning it was undoubtedly a few degrees higher than this, but no other Hymenoptera whatever were observed to be active at this time. Indeed, there was no considerable amount of Hymenoptera activity in this area until about 9:00. Yet Sericophorus viridis appears specially adapted for performing under these conditions of cool temperatures and long shadows. Only one instance of prey carriage was recorded after $8: 00$, a situation in striking contrast to the behavior of the following species, $S$. relucens. Similar early morning hunting was also reported, however, for $S$. teliferopodus in Victoria, and according to Rayment (1955b) this species also preyed exclusively on blowflies, utilizing only the males. This led us to inquire as to the sex of our sample, and Dr. D. H. Colless reports that in fact all of the nearly Ioo blowflies we recovered from nests of $\mathcal{S}$. viridis were males.

This puzzling behavior is more understandable if one considers 

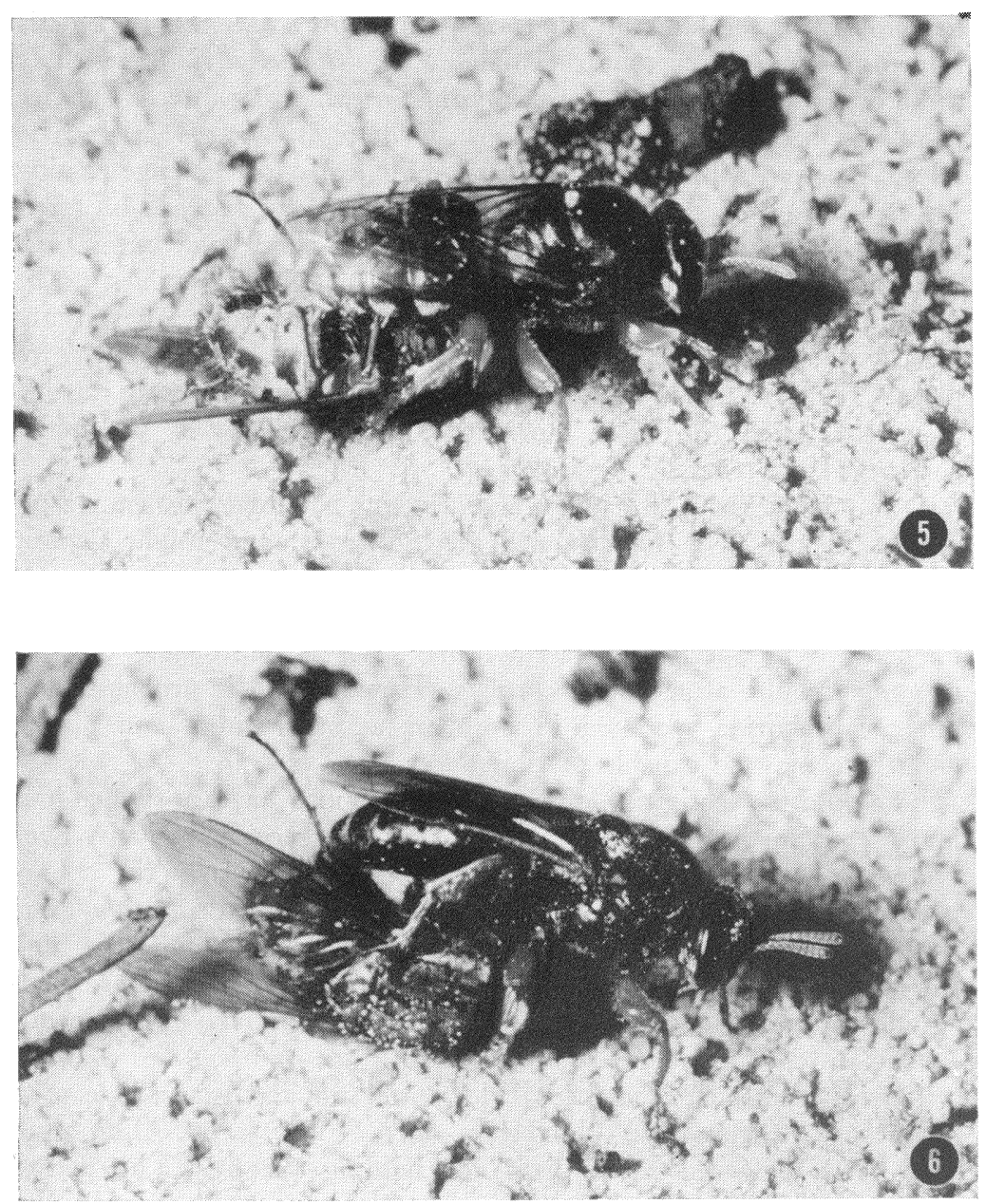

Figs. 5-6. Two views of female Sericophorus viridis with prey. These females have landed on the ground near their nests and will shortly proceed to them. Note that the fly is held well back, beneath the abdomen of the wasp, the hind legs embracing the back of the fly's thorax. In most cases the fly is venter-up, as in Fig. 5; carriage of the fly sideways (Fig. 6) is exceptional. 
the biology of the blowflies that are used as prey. Dr. K. R. Norris informs us (in litt.) that the males of Calliphora tibialis resemble those of some of the carrion calliphorids in exhibiting intense activity from just before dawn until at most an hour afterward. Each male selects a perch from which it flies off periodically to challenge passing insects. Dr. Norris believes that this may be an instance of territoriality, as males often appear on the same perch time after time and may engage in aerial combat with neighboring males. The females, on the other hand, do not exhibit this behavior and are usually to be found on the ground or moving about from place to place. Thus the males would be especially available to a wasp capable of attacking in the early morning hours, especially if the males challenged approaching Sericophorus.

It: is possible, too, that there is a selective advantage in the wasps' use of males. The females are ovoviviparous, and might deposit maggots in the cells which could destroy the wasp egg or larva, as sometimes occurs in Bembix (Evans, 1957, p. 77). C. tibialis happens to be specific to earthworms, so it is improbable that its maggots would attack wasp larvae. However, it is probable that other calliphorids are used in numbers at other times and places, and these may be capable of doing so.

The hunting activities of Sericophorus must have a tremendous impact on the host fly populations. Estimating conservatively, over 50,000 male $C$. tibialis are captured and entombed by the colony behind C. S. I. R. O. in a single season (i.e., roo active nests $X$ IoO days $X 5$ flies per day per wasp)! Such an apparent high degree of host specificity is possible only when the prey are continuously available and themselves maintain relatively large populations.

During transport, the fly is held venter up and grasped near its wing base by the wasp's hind legs only (Figs. 5, 6). The sting was never observed to be used for holding the fly. The wasps' flight is swift and noiseless, the females reappearing suddenly. Typically the prey-laden wasp lands on the edge of her nest mound and quickly plunges into the open entrance; rarely she lands on the ground nearby and walks to her nest. Walking is done in a somewhat jerky manner, the wings held flat over the body, with no flicking. During the period of active provisioning, several trips for prey are made in rather rapid succession, with little time spent in the nest between trips. Whereas in $S$. victoriensis two or more adults are reported to utilize the same nest (Rayment, I955a), this was never observed in $S$. viridis. The females appear to spend the 

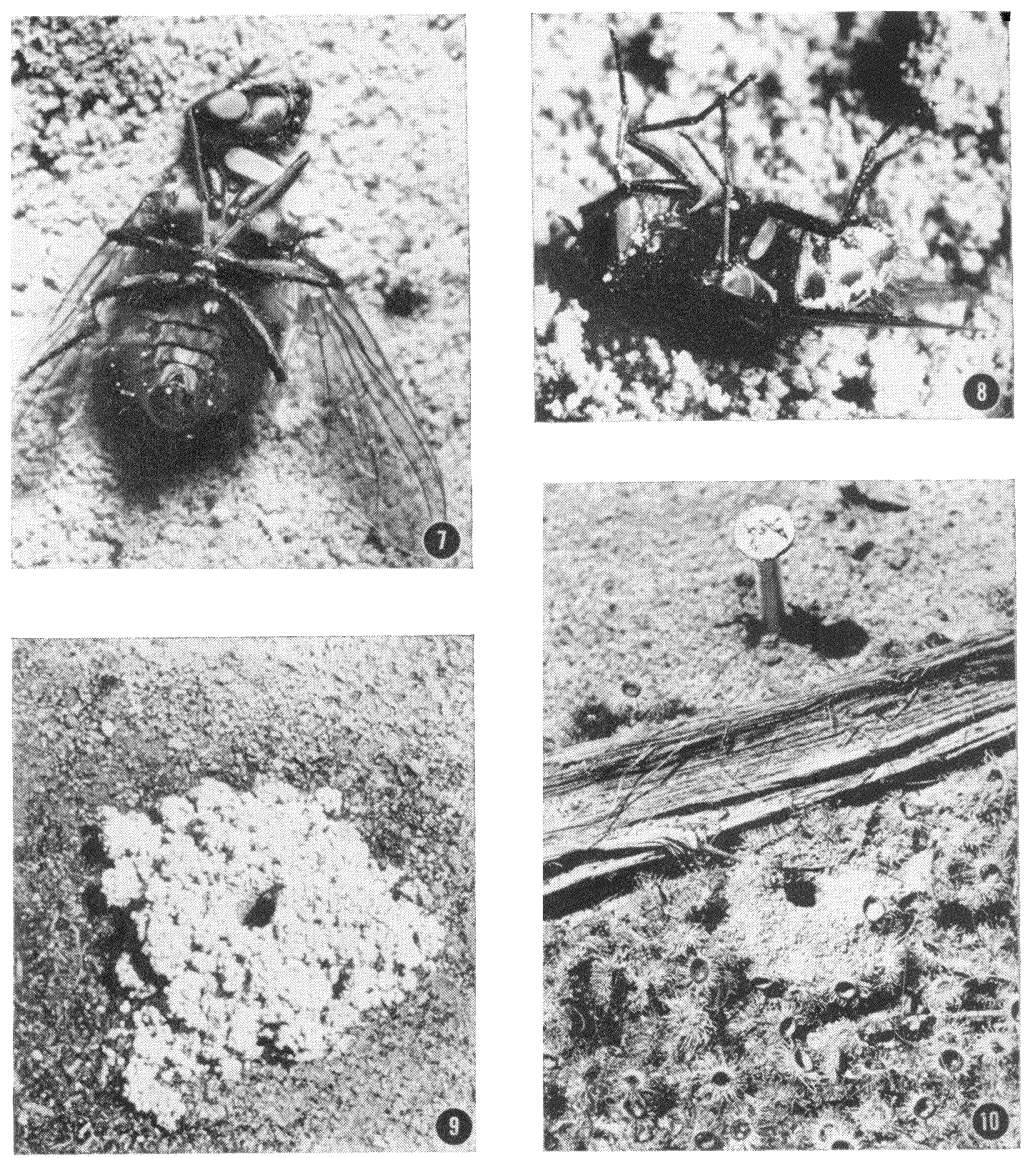

Fig. 7. Egg of Sericophorus viridis on prey, a male Calliphora tibialis. Fig. 8. Egg of the parasitic wasp, Acanthostethus portlandensis, on a Calliphora tibialis from a nest of Sericophorus viridis. Fig. 9. Typical nest entrance of $S$. viridis, Canberra, A. C. T. Fig. 10. Nest entrance of S. relucens, AM 122, near Peak Hill, N. S. W. Debris from Eucalyptus inflorescences has accumulated on the lee side of a stick; a nail used as a nest marker is above the nest. 
night within their nests, the entrances closed from within. However, during the day our impresson was that about half of the nests in the colony were left open at any given time.

No final closing behavior was observed. However, while the lateral tunnels leading to the individual cells are always refilled following provisioning, the main vertical nest shaft is apparently never filled in, and the mound remains to be eventually eroded by the elements. Possibly the female constructs a simple plug in the entrance of completed nests, as we occasionally observed the entrances of formerly active nests to be plugged with debris, mostly short pieces of grass stems and other dried plant parts. Whether these apparent final closures were the work of the wasps or the elements is unknown. However, related miscophine wasps in the genus Solierella often close the burrow with assorted debris, including seeds, small twigs, leaves, and sand grains (Kurczewski, 1967). We occasionally noted unidentified spiders occupying former nests, and Rayment ( $1955 \mathrm{a}, \mathrm{b}$ ) reports that certain pompilid wasps sometimes utilized the abandoned Sericophorus burrows.

A brief description of two nests of $S$. viridis roddi Rayment (a subspecies of doubtful validity) from Cheltenham, N.S.W., is reported by Rayment (1955b); these nests appear similar in form to those of the Black Mountain colony. Also, Rayment reported that males were observed flying over a different $S$. viridis roddi colony at Tallong, N.S.W., in the early summer and were often seen to enter closed nests. On the basis of these observations, he suggests that mating may take place below ground. As we did not discover the Black Mountain colony until the nesting season was well under way, and never noted evidence of males, we are unable to add any information on this aspect of their biology.

Egg and Larval Development. - Prey are placed in the cell head in first, usually venter up, and are strung out more or less in a row. The flies are dead or profoundly paralyzed, and remain relaxed but wholly immobile for several days. In I 7 cells containing eggs, the number of flies per cell averaged 5.6 (range 3-9).

The egg is laid on the first fly placed in the cell (occasionally apparently on the second $\mathrm{fly}$ ), i.e., the fly at the end of the cell farthest from the main nest shaft. Cells are mass provisioned, but apparently the egg is not laid until after the full complement of flies has been placed in the cell, as on several occasions excavated nests were found having cells with one or more flies present but containing no egg. As in the species studied by Rayment (1955a, b), 
the egg is attached ventrally and more or less transversely on the prothorax just anterior to the fore coxae and slightly off center to one side (Fig. 7). According to Rayment, one anterior leg of the egg-bearing fly is sometimes dislocated or raised; however, this was not observed in $S$. viridis.

Eggs are whitish and sausage-shaped, measuring $2.5 \mathrm{~mm}$ long by $0.5 \mathrm{~mm}$ wide at the middle. No data were obtained on time required for egg hatch or larval development; however, Rayment (1955b) gives the incubation period for $S$. teliferopodus eggs as between 4 and 6 days, with larval development requiring about I2-I 4 days. Normally only one or possibly two new cells appeared to be stocked each morning, a rate possibly determined by availability of mature eggs in the females' ovaries. The most cells in a single nest that contained eggs was three.

Larval characters. - The following description is based on two fully grown, non-diapausing larvae from Canberra (note nos. A 260, AM 217). Notes on several diapausing larvae removed from cocoons follow the description.

Body length $9.5 \mathrm{~mm}$; maximum width $3.3 \mathrm{~mm}$. Robust, more tapered anteriorly than posteriorly; dorsal profile somewhat serrate, each segment somewhat expanded posteriorly, without distinct division into annulets; terminal segment rounded beyond the broad, ventral anal opening; pleural lobes prominent, rounded protuberant, the thorax without prominent accessory lobes although prothorax with prominent pleural lobes and with small latero-dorsal swellings (Fig. I2). Spiracles small, lightly pigmented; atrium lined with weak, irregular hexagons; opening into subatrium simple, unarmed; subatrium swollen, of irregular shape (Fig. I6). Integument mainly smooth, but entire venter minutely spinulose; each segment with a few very short setae dorsally, the pronotum with somewhat more setae than following segments (about 20, these about the same length as the head setae).

Head $1.2 \mathrm{~mm}$ wide, I.I $\mathrm{mm}$ high (not including labrum and mouthparts) (Fig. II). Parietal bands and coronal suture absent; top and sides of head roughened by many small convexities; antennal orbits small, subcircular, each bearing three minute sensilla; head setae sparse but moderately long, the longest ones measuring about $60 \mu$; clypeus with a double row of setae. Labrum weakly emarginate medially, its surface with numerous strong setae, median apical margin also with a few setae; margin with only a few, weak sensory cones, rather roughly spinulose laterally; epipharynx covered with 

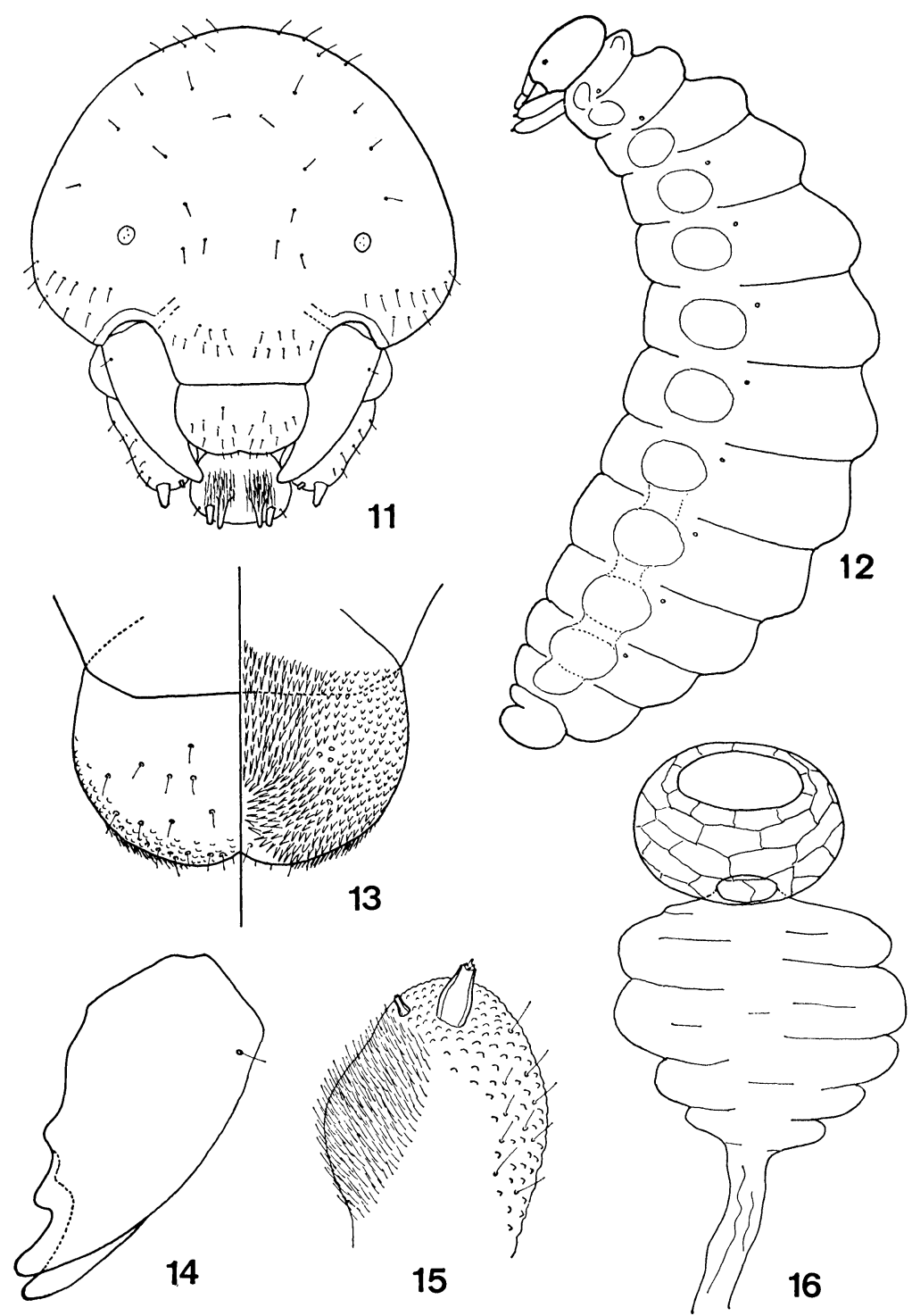

Figs. 11-16. Sericophorus viridis Saussure, mature non-diapausing larva. Fig. 11. Head, anterior view. Fig. 12. Body, lateral view. Fig. 13. Labrum (left) and epipharynx (right). Fig. 14. Mandible, dorsal aspect. Fig. 15. Maxilla, mesal margin at left. Fig. 16. Spiracle. 
long spinules, medially and apically, these tending to converge toward the midline; extreme sides of epipharynx with only short, sparse spinules (Fig. I3). Mandibles approximately twice as long as their basal width, terminating in five teeth, the basal two smaller than the apical three; base of mandibles with a single seta (Fig. I4). Maxillae directed mesad, their inner margin somewhat lobed, strongly spinulose; palpi large, about $80 \mu$ in length; galeae very much smaller than palpi, only about $25 \mu$ in length (Fig. 15). Apical portion of labium circular, bearing two patches of long spinules on its oral surface; palpi about $70 \mu$ long, slightly exceeded by the spinnerets.

In larvae removed from cocoons after passing their meconium, the body is much more compact, the segments being shortened but with very strong pleural lobes and transverse dorsal elevations; the anterior part of the body is curved strongly and pressed against the venter, the head being invisible or nearly so. Head features are unchanged except that the maxillae and labium are somewhat flattened and the spinnerets difficult to detect.

The larvae agree well with the characters of the Larrinae as defined by Evans (1958, 1964). In features of the epipharynx, Sericophorus approaches Liris most closely, and there is good agreement in general form of the body and head with that genus. In the artificial key to sphecid larvae (Evans, 1959, p. I7 I) the larva of Sericophorus runs reasonably smoothly to Motes (i.e., Liris). However, the described larvae of Liris have a much more hirsute body and a non-emarginate labrum. There is a reasonably close resemblance to the larvae of such genera of Miscophini as Lyroda and Plenoculus, but those genera have more finger-like prothoracic lobes and a different arrangement of generally much shorter spinules on the epipharynx. The larvae of these four genera show no really important differences and do not reflect the major differences in nesting behavior among them.

Cocoon. - Cocoons measure $\mathrm{I} 2-14 \mathrm{~mm}$ long by $5.5-6.5 \mathrm{~mm}$ maximum width; they are rounded at both ends but very slightly more tapered toward one end than the other (Fig. I7). The walls are composed of soil particles glued together to form a thin, brittle case; there is no silken lining and there are no evident pores in the walls (as there are in Bembicini). The soil grains are evidently fastened together with viscid strands of silk. The walls of the cocoon are relatively smooth on the inside, quite rough on the outside.

Natural Enemies. - The nyssonine wasp, Acanthostethus port- 
landensis (Rayment) was common in the nesting area throughout the season. It was often observed to investigate, and sometimes to enter, open nests, and actively patrolled the nesting area throughout the day. With the exception of some miltogrammine flies noted on one occasion but not collected, no other parasites were observed in the nesting area.

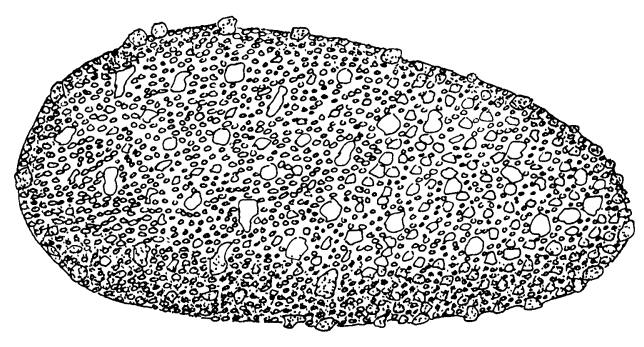

17

Fig. 17. Cocoon of Sericophorus viridis, anterior end at right.

Of I7 cells with Sericophorus eggs (and several more incompletely provisioned cells), only one contained evidence of parasitism (note AM I 43). This cell contained 8 flies with the egg of Sericophorus on the fly deepest in the cell. However, a somewhat smaller egg, presumably that of Acanthostethus, was found on the fourth fly in the cell, tucked ventrally just posterior to the left hind coxa and well concealed between it and the base of the fly's abdomen (Fig. 8). The parasite egg measured $1.3 \mathrm{~mm}$ long and $0.5 \mathrm{~mm}$ wide at the middle. Attempts to rear the parasite in a tin failed.

Rayment (1953, 1955a) first discovered this interesting wasp entering nests of $S$. victoriensis, and his account of its behavior is essentially the same as we have observed, although he failed to find its eggs or immature stages. He also mentioned the presence of several unidentified mutillids and the bombyliid Systoechus sp. in the vicinity of the Sericophorus nests.

In our nests, mold was an important mortality factor. For example, in the largest nest excavated, viable offspring were found in I 4 cells ( I c cocoons, 2 larvae, I egg), but an additional 9 cells were overgrown with mold. Another seven nests excavated on the same day (4 March 1970) contained a total of 50 cells of which 27 had been destroyed by mold. 
Sericophorus relucens Smith

According to Rayment (1955b), S. relucens is one of the commonest and most widely distributed Sericophorus species in Australia. However, in contrast to nests of the gregarious $S$. viridis, nests of $S$. relucens were never found in abundance. Indeed, all were discovered when the female was observed to return suddenly to a spot and disappear into the ground. The largest number of nests found in a given locality was three at 8 miles north of Peak Hill, N.S.W. (AM II2-I I4) on I I December 1969. Here S. relucens nested in a flat area of rather coarse and moderately packed sand, at the base of eroded slag heaps of an abandoned mining operation. Other wasps nesting here included Bembix lamellata Handlirsch, B. raptor Smith, Bembecinus hirtulus (Smith), and Cerceris minuscula Turner. Additional single nests were found about $2 \mathrm{~m}$ above flood level on the west bank of the Murrumbidgee River at Pine Island Reserve, Io miles south of Canberra, A.C.T., on ro January 1970 (AM 152) and on the south bank of Baker's River, 5 miles S. Machay, Qld., on 2 May 1970 (AM 232). ${ }^{2}$ Both were in moderately friable loamy sand with sparse vegetation. Nests of Bembix trepida Handlirsch, Bembecinus hirtulus (Smith), and Prionyx globorus (Smith) occurred in the same general area at Pine Island Reserve, and Bembecinus egens (Handlirsch) and Bembix raptor nested commonly at the Mackay site.

Nest Structure. - The five excavated nests were of typical sericophorine form, consisting of a vertical main shaft $8-13 \mathrm{~cm}$ long and one or two cells at the end of short $2-3 \mathrm{~cm}$ long lateral tunnels frim the bottom of the main burrow. Typical nest profiles are illustrated in Figures 3 and 4. The relatively inconspicuous mounds or tumuli encircling the nest entrances measured $2.5-3.0 \mathrm{~cm}$ across. Those of the Peak Hill nests were marked by accumulated piles of wind-blown plant debris, consisting mostly of dried Eucalyptus inflo:escence parts (Fig. Io). All of the Peak Hill nests were situated adjacent to sticks which littered the soil surface and appeared to act as miniature windbreaks.

The most cells found in any nest was two, and it seems likely that this is the maximum number per nest made by this species. Supporting this was the fact that no cells containing mature larvae or cocoons were ever found; cells always contained fresh flies. Typically both cells were situated at about the same depth and on opposite sides

\footnotetext{
${ }^{2}$ Specimens were collected at all three localities and found to compare very favorably with the type specimen of relucens Smith, which we studied in the British Museum (Natural History).
} 
of the main burrow (Fig. 4), an architecture similar to that of $S$. teliferopodus (Rayment, I955b).

Unlike $S$. viridis, females of $S$. relucens were observed to return to the nests with prey throughout the day, a behavior similiar to the daytime hunting reported for $S$. sydneyi and $\mathcal{S}$. victoriensis (Rayment, I955a, b). The wasps' flight is silent, and upon returning they plunge quickly and without hesitation into their open nest entrances. The sample of prey removed from the eight excavated cells included 13 species belonging to four families (see Table I), a much broader range than that taken by $S$. viridis. The strongest preference appeared to be shown for the sarcophagid, Tayorimyia iota (Johnston and Tiegs), which conprised 7 of the Io flies in the Pine Island Reserve nest, and 5 of the 18 flies from the Peak Hill nests. Interestingly, two individuals of Calliphora tibialis (the major prey of $S$. viridis) were found in one nest from the Peak Hill colony.

In contrast to the all male prey taken by $S$. viridis (and indeed the prey of all the species studied by Rayment), $S$. relucens prey samples included a small proportion of female flies ( 5 of 18 from Peak Hill, 3 of ro from Pine Island Reserve; all 5 from Mackay were males). However, none of these females belonged to the Calliphoridae, although calliphorids comprised $\mathrm{I} / 3$ of the total prey sample. Certainly the matter of prey selection by Sericophorus is worthy of further investigation, particularly as it is related to time of hunting and the reproductive characteristics of the preferred prey.

The flies are strung out in a row in the cell, head in first and usually venter up. Three cells which were apparently complete (i.e., situated at the ends of filled lateral tunnels), were accidentally broken into during excavations, but no eggs or larvae were subsequently recovered. Nevertheless, the number of prey in these cells $(6,7$ and 7$)$ is probably representative of the normal prey complement per cell for $S$. relucens.

Natural Enemies. - No parasites were recovered from the nests, but the mutillid Ephutomorpha mackayensis André. was common at the Peak Hill site, and one female was observed walking around the entrance of one of the Sericophorus nests (AM II4).

\section{ACKNOWLEDGEMENTS}

We are deeply indebted to the Division of Entomology, CSIRO, Canberra, for use of their facilities during the period of study. The flies were identified by K. R. Norris (Calliphoridae) and D. H. 
Colless (all other families), both of the above address. We are also indebted to Drs. Colless and Norris for information on the sex and biology of the flies used as prey. Specimens of the prey, wasps and associated parasites have been deposited in the Australian National Insect Collection, Canberra, and in the Museum of Comparative Zoology, Harvard University, Cambridge, Massachusetts, U. S. A. These bear our note numbers as referred to in the text.

Evans, H. E.

\section{Literature Cited}

1957. Studies on the Comparative Ethology of Digger Wasps of the genus Bembix. Comstock Publ. Assoc., Ithaca, N. Y., 248 pp.

1958. Studies on the larvae of digger wasps. Part IV. Astatinae, Larrinae and Pemphredoninae. Trans. Amer. Entomol. Soc., 84: 109-139.

1959. Studies on the larvae of digger wasps. Part V. Conclusion. Trans. Amer. Entomol. Soc., 85: 137-191.

1964. Further studies on the larvae of digger wasps (Hymenoptera; Sphecidae). Trans. Amer. Entomol. Soc., 90: 235-299.

KURCZEWSKI, F. E.

1967. A note on the nesting behavior of Solierella inermis (Hymenoptera: Sphecidae, Larrinae). J. Kans. Entomol. Soc., 40: 203208.

RAYMENT, T.

1953. New bees and wasps. Part 21. Parasites on sericophorine wasps. Victorian Nat., 70: 123-127.

1955a. Biology of two hunting wasps. The specific descriptions of a new species and one allotype of Sericophorus and a new blowfly Pollenia. Australian Zool., 12: 132-141.

1955b. Taxonomy, morphology and biology of sericophorine wasps. With diagnoses of two new genera and descriptions of forty new species and six sub-species. Mem. Natl. Mus. Victoria, 19: $11-105$.

RIEK, E.

1970. Hymenoptera. [In The Insects of Australia, sponsored by the Division of Entomology, CSIRO, Canberra. Melbourne Univ. Press, 1029 pp.]. 

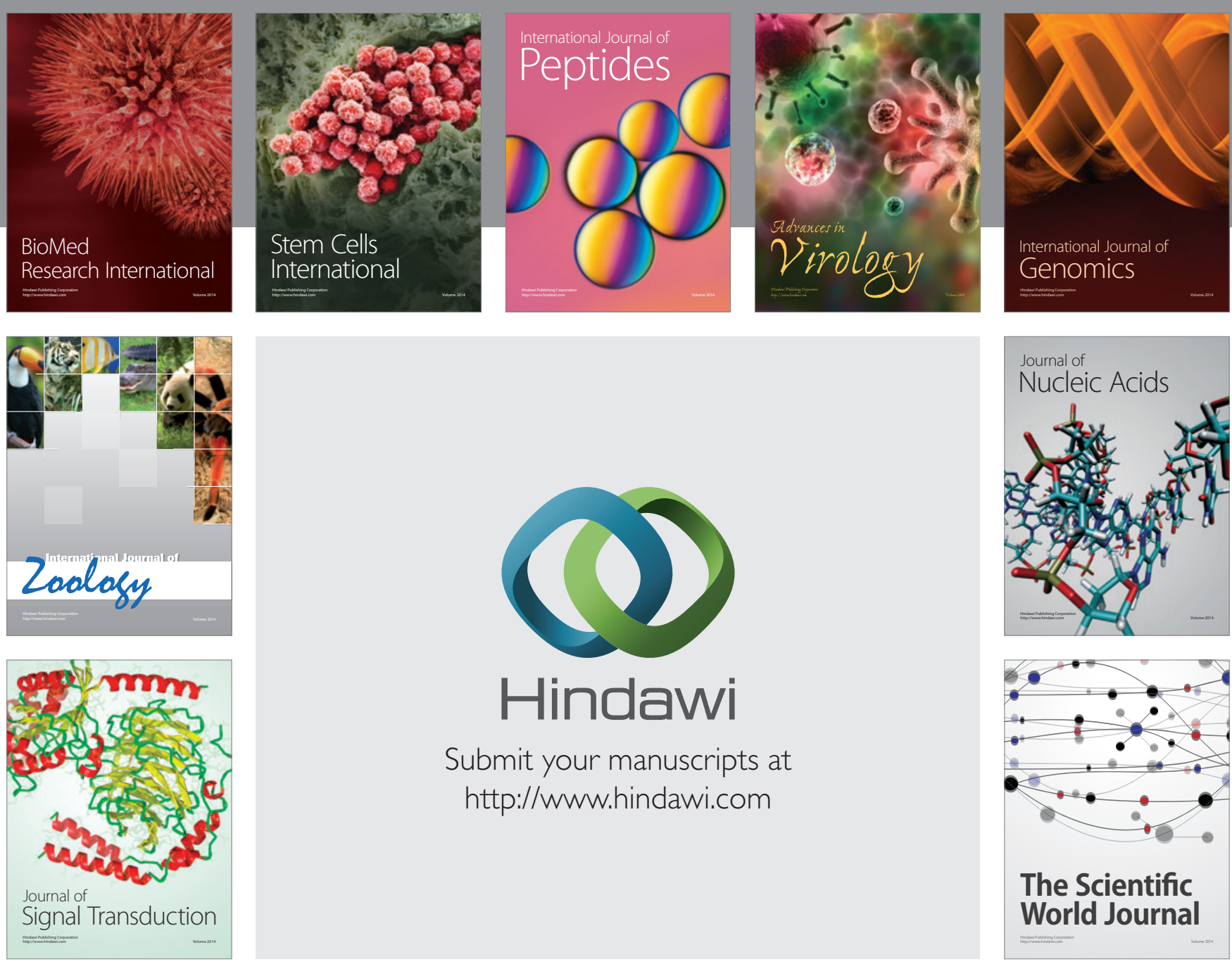

Submit your manuscripts at

http://www.hindawi.com
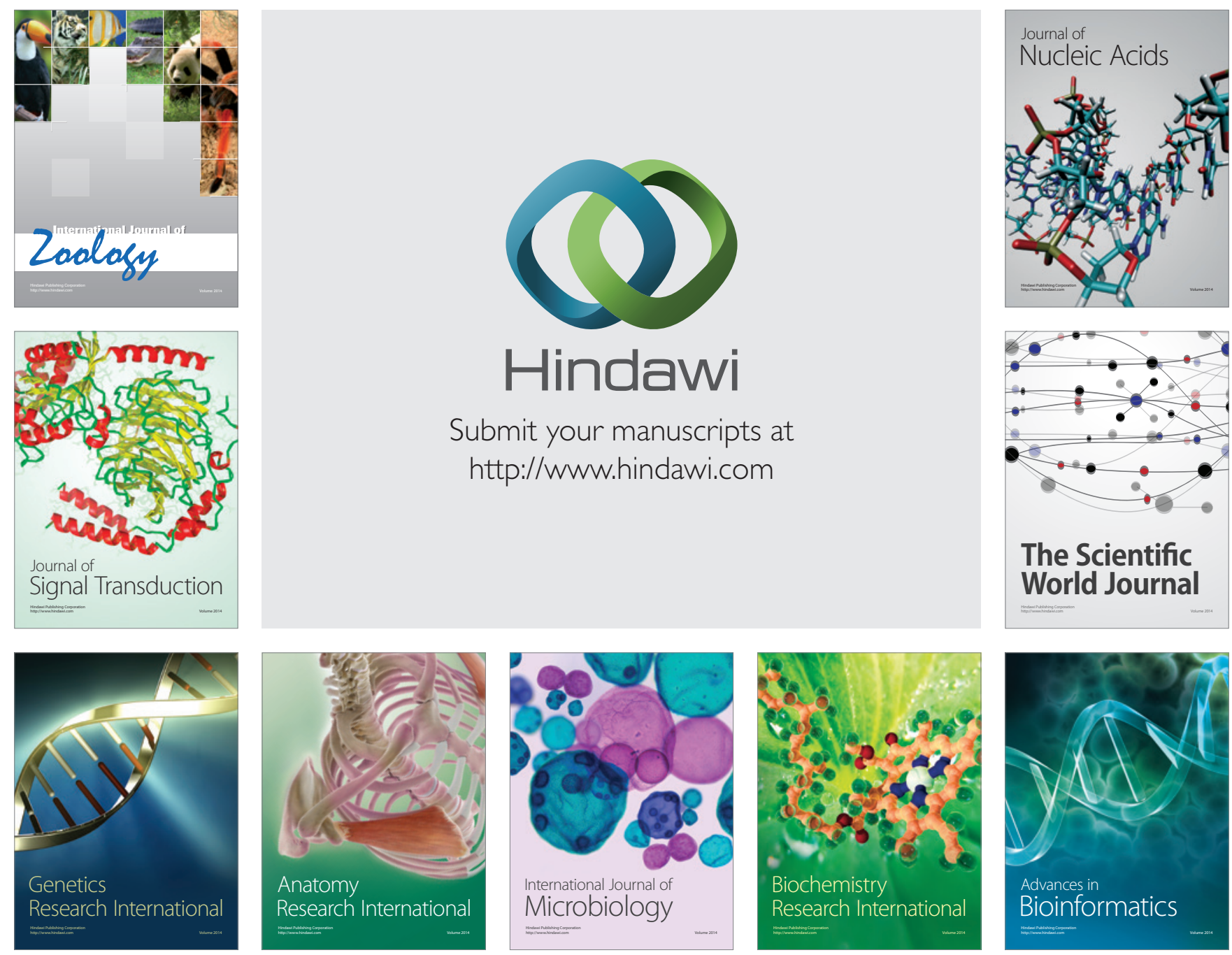

The Scientific World Journal
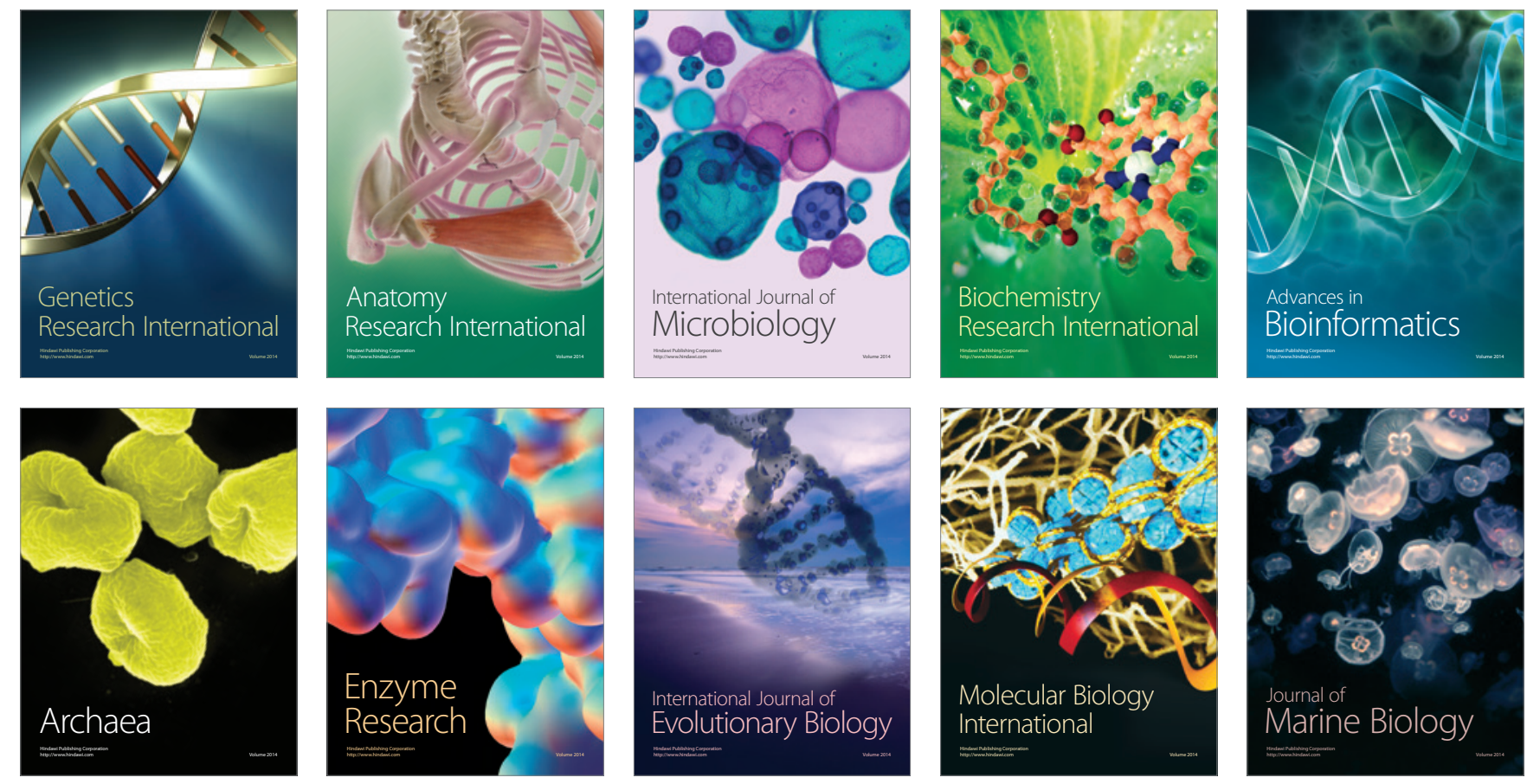